\title{
Harvinaissairaiden käsityksiä sairaudesta ja sitä koskevan tiedon kognitiivisista auktoriteeteista
}

\author{
Annika Rotonen \\ annika.rotonen@gmail.com \\ https://orcid.org/0000-0002-6281-7513 \\ Noora Hirvonen \\ Oulun yliopisto \\ noora.hirvonen@oulu.fi \\ https://orcid.org/0000-0001-7577-3057 \\ Maija-Leena Huotari \\ Oulun yliopisto \\ maija-leena.huotari@oulu.fi \\ https://orcid.org/0000-0001-7789-3079
}

This article examines illness representations as viewed by Finnish adults with a hereditary rare disease, and ways these representations manifest in their information behaviour, focusing on the cognitive authority of information sources. Data were gathered with five theme interviews and analysed using theory bound content analysis. The results show that doctors and researchers specialised in rare diseases had a central cognitive authority status among the patients. Additionally, personal expertise and experience, and peer information, particularly of practicalities, were also crucial. Information sources, and information provided by the sources, were significant in constructing illness representations and for controlling the disease. The core information sources and their evaluation varied in different disease phases and along with evolving illness identity. The results cannot be generalised to all Finnish adults with a rare disease but they add knowledge about patients' views of information sources in a situation where information is scarce. Because of the general lack of information about rare diseases, information supply, information behaviour and information creation are examples of prolific study subjects.

Asiasanat: harvinaiset taudit, sairauskäsitykset, informaatiokäyttäytyminen, tiedonlähteet, arviointi

VERTAISARVIOITU

KOLLEGIALT GRANSKAD

PEER-REVIEWED

www.tsv,fi/tunnus

Artikkeli on lisensoitu Creative Commons Nimeä-EiKaupallinen-JaaSamoin 4.o Kansainvälinen -lisenssillä 


\section{Johdanto}

Erilaisia harvinaisia sairauksia on tuhansia. Yksittäisten, harvinaisten sairauksien tutkiminen ei kuitenkaan yleensä ole tutkimuksen keskiössä, sillä yleisemmät, suoremmin kansanterveyteen vaikuttavat sairaudet vievät usein tutkijoiden ja muiden asiantuntijoiden huomion (Laitinen, Malkamäki, Saari \& Vataja 2013). Sairauksien tuntemattomuus ja puute niitä koskevasta tiedosta vaikuttaa merkittävästi sairastuneiden elämään, tuoden myös muita haasteita arkeen. Tieto voi auttaa ihmistä ymmärtämään, hoitamaan ja käsittelemään omaa sairauttaan (Spring 2014a), joten tiedon puuttuminen on sairastuneille ongelmallista.

Harvinaisiksi sairauksiksi (myös harvinaissairaus, harvinainen tauti; eng. rare disease, rare disorder) määritellään sairaudet, joiden esiintyvyys on enintään viisi henkilöä 10 ooo ihmistä kohden (Harvinaiset-verkosto 2020a). Harvinaissairauksia on eri arvioiden mukaan noin 5000-8000 (Harvinaiset-verkosto 2020a, Euroopan komissio 2020). Suomessa harvinaissairaita on arviolta 300 ooo (Laitinen ym. 2013). Koko Euroopan Unionin (EU) alueella sairastuneita on noin 27-36 miljoonaa (Euroopan komissio 2020). Tämä tarkoittaa sitä, että jopa kahdeksan prosenttia EU:n väestöstä sairastaa harvinaista sairautta.

Noin 70 prosenttia harvinaissairauksista on perinnöllisiä. Lisäksi sairaudet voivat johtua infektioista, allergioista tai ympäristötekijöistä (Eurordis 2020). Niiden perinnöllisestä luonteesta johtuen tietyt harvinaissairaudet ovat yleisempiä joillakin alueilla (Orphanet 2012). Vaikka harvinaiset sairaudet eroavat toisistaan hyvin paljon, niitä yhdistävät monet samankaltaiset piirteet kuten sairauden etenevyys, kroonisuus, heikentävyys ja hengenvaarallisuus. Myös tehokkaiden parannuskeinojen puute on harvinaissairauksien kohdalla yleistä. On tavallista, että yksilökohtaisesti saman sairauden vakavuusaste sekä oireet voivat olla toisistaan hyvinkin poikkeavia samaa harvinaissairautta sairastavien kesken (Eurordis 2020). Lisäksi harvinaissairaat kohtaavat usein ongelmia, jotka liittyvät sairauden sosiaalisiin seurauksiin, diagnosointiin, tiedon puutteeseen, asiantuntevien terveydenhuollon ammattilaisten löytymiseen sekä hoitokeinoihin (Orphanet 2012, Eurordis 2020).

Tämän artikkelin tavoitteena on kuvata harvinaissairaiden aikuisten käsityksiä heidän omasta sairaudestaan ja näiden käsitysten ilmenemistä heidän informaatiokäyttäytymisessään. Tarkastelun kohteena on sairauskäsitysten ilmeneminen erityisesti siinä, miten harvinaissairaat arvioivat sairauttaan koskevaa tietoa ja tiedonlähteiden kognitiivista auktoriteettia.

Artikkeli perustuu informaatiotutkimuksen pro gradu -tutkielmaan (Rotonen 2020). Aihepiirin tutkimuksessa on informaatiotutkimuksen alalla selkeä 
aukko, jota tämä artikkeli sekä edellä mainittu tutkielma pyrkivät osaltaan täyttämään.

\section{Kirjallisuuskatsaus}

Tässä luvussa tarkastellaan harvinaissairauksiin ja niitä koskevaan tietoon sekä sairauskäsityksiin ja harvinaissairauksia koskevaan tiedonhankintaan liittyvää tutkimusta, jonka jälkeen eritellään tutkimuksia sairautta koskevan tiedon kognitiivisista auktoriteeteista. Luvun lopussa esitetään tutkimuksen tavoite sekä tutkimuskysymykset.

\section{Harvinaissairaudet ja niihin liittyvä tieto}

Informaatiotutkimuksen näkökulmasta tehtyä tutkimusta harvinaisista sairauksista on hyvin vähän. Kirjoittajien tiedon mukaan tätä tutkimusta ei ole tehty Suomessa lainkaan lukuun ottamatta pro gradu -tutkielmaa (ks. Rotonen 2020), johon tämä artikkeli pohjautuu. Myöskään sairauskäsityksiä ei ole informaatiotutkimuksen alalla juuri tutkittu. Poikkeuksen tekevät Stanarević Katavićin ja tutkijakollegoiden (2016, 2019) Kroatiassa toteutetut tutkimukset, joissa on tarkasteltu harvinaissairaiden informaatiokäyttäytymistä (Stanarević Katavić, Faletar Tanacković \& Badurina 2016, Stanarević Katavić 2019) sekä sairauskäsitysten yhteyksiä informaatiokäyttäytymiseen (Stanarević Katavić ym. 2016). Muilla tieteenaloilla, erityisesti hoitotieteissä, aihepiirin tutkimusta on kuitenkin tehty ja näissä tutkimuksissa on tarkasteltu informaatiotutkimuksen näkökulmasta kiinnostavia ilmiöitä. Tiedon puute on eräs harvinaissairauksia yhdistävistä tekijöistä ja määrittelee näitä sairauksia.

Harvinaissairauksista on yleisesti saatavilla niukasti lääketieteellistä tietoa ja myös asiantuntevista ammattilaisista on puutetta (Eurordis 2020). Sairastuneilla ja heidän läheisillään on kokemusta sairaudesta, sen oireista ja hoidosta ja niinpä harvinaissairauksien kontekstissa heidän asiantuntemuksensa korostuu. Tämän vuoksi myös erilaiset tukiryhmät ja -järjestöt sekä vertaiset nousevat tärkeiksi tiedonlähteiksi (Spring 2014b). Paitsi tiettyyn harvinaissairauteen, diagnosointiin, oireisiin, hoitoon, sairauden hallintaan, ennusteeseen ja asiantuntevien terveydenhuollon ammattilaisten löytämiseen liittyvää informaatiota (Morgan ym. 2014), harvinaissairaat tarvitsevat usein myös sosioemotionaalista tukea (Lasker, Sogolow \& Sharim 2005, Mooney, Poland, Spalding, Scott ja Watts 2013). Vertaistuki ja positiiviset tunteet ovat nousseet esille esimerkiksi sappikirroosia sairastavien (Lasker ym. 2005) sekä 
pitkäaikaissairaiden ja vammaisten lasten ja nuorten vanhempien (Kalmari \& Taanila 2014) kohdalla. Vertaiset tarjoavat henkistä tukea ja jakavat kokemuksiaan sekä esimerkiksi arkielämää helpottavaa tietoa ja käytännön vinkkejä (Kalmari \& Taanila 2014, Harvinaiset verkosto 2020b).

Laitisen ja muiden (2013) harvinaissairailta ja heidän läheisiltään kerättyyn kyselyaineistoon perustuva selvitys osoitti, että tiedon puute toi haasteita paitsi arkielämän eri puoliin, myös diagnoosin saamiseen. Erityisesti suomenkielinen informaatio sekä tieteellinen tutkimus tulivat esille keskeisinä tiedontarpeina. Osa osallistujista koki kuitenkin tiedon saannin parantuneen vuosien saatossa. Tietoa saatiin erikoissairaanhoidosta, internetistä, järjestöiltä tai yhdistyksiltä sekä vertaisilta (Laitinen ym. 2013). Carpenter ja muut (2011) tutkivat vaskuliittipotilaiden käyttämiä lääkitykseen liittyviä tiedonlähteitä. Tietoa hankittiin tyypillisesti lääkäreiltä ja internetistä ja näihin myös luotettiin eniten. Painettuja lähteitä, tukiryhmiä ja muita terveydenhuollon ammattilaisia sen sijaan käytettiin tiedonlähteinä vain harvoin. Ystävät ja perheenjäsenet olivat harvimmin käytettyjä tiedonlähteitä, tosin miehet pitivät puolisoitaan luotettavina tiedonlähteinä melko usein (Carpenter ym. 2011). Hamiltonin ja muiden (2015) tutkimuksessa kävi ilmi, että tietoa omasta tai läheisen sairaudesta haettiin useimmiten internetistä, mutta myös terveydenhuollon ammattilaisilta sekä vertaisilta.

\section{Sairauskäsitys ja harvinaista sairautta koskeva tiedonhankinta}

Terveystiedon hankinta voidaan ymmärtää keinoksi sopeutua harvinaiseen sairauteen. Leventhalin ja tutkijakollegoiden (2012) arkijärjen malli (eng. Common Sense Model, CSM) on teoreettinen viitekehys, jonka avulla pyritään ymmärtämään ihmisten sopeutumista terveyteen liittyviin uhkiin eri konteksteissa (Leventhal, Bodnar-Deren, Breland, Hash-Converse, Phillips, Leventhal \& Cameron 2012). Mallin keskeinen käsite on sairauskäsitys (eng. illness perception, illness representation), joka kuvaa ihmisten kognitiivisia malleja tai uskomuksia sairauksista, oireista sekä terveysuhkista (Benyamini 2011; tässä Stanarević Katavić ym. 2016). Kun ihminen huomaa itsessään ruumiillisia muutoksia tai tuntemuksia, jotka eroavat normaalista, sairauskäsitykset voivat aktivoitua (Leventhal ym. 2012). Leventhalin ja muiden (2012) mukaan sairauskäsitysten syntymiseen vaikuttaa viisi ulottuvuutta: sairausidentiteetti, sairauden aikajana, sairauden koetut ulkoiset, sisäiset tai käyttäytymiseen liittyvät syyt, oletetut ja koetut seuraukset sekä sairauden hallinta.

Sairaus ja terveys liittyvät läheisesti toisiinsa. Yksinkertaistaen terveys voidaan käsittää suppeasti tai laajasti: suppeasti sairauden tai vaivan poissaolona tai laajasti fyysisenä, psyykkisenä ja sosiaalisena hyvinvointina (Brüs- 
sow 2013). Laaja terveyskäsitys huomioi subjektiivisen kokemuksen omasta terveydestä: myös parantumattomasti sairas voi kokea olevansa terve (Huttunen 2020).

Stanarević Katavić ja muut (2016) hyödynsivät sairauskäsitys-käsitettä tarkastellessaan kroatialaisten aikuisten harvinaissairaiden sairauskäsityksiä ja niiden yhteyttä heidän informaatiokäyttäytymiseensä. Heidän toteuttamansa kyselytutkimuksen mukaan sairauskäsitykset olivat yhteydessä informaatiokäyttäytymiseen. Oman sairauden ymmärtämistä edisti, että harvinaissairas käytti potilasjärjestöjä tiedonlähteenä. Tutkijat huomasivat kuitenkin myös, että mikäli tiedonlähteenä käytettiin yleislääkäriä, verkkoryhmiä tai perheenjäseniä, tunnettiin suurempaa huolta omasta harvinaissairaudesta. Samaa sairautta sairastavan vertaisen tunteminen auttoi vähentämään huolta ja lisäämään ymmärrystä ja hallinnan tunnetta. Pelkkä vertaispotilaiden tiedonlähteenä käyttäminen ei kuitenkaan vaikuttanut olevan merkittävässä yhteydessä sairauskäsitykseen (Stanarević Katavić ym. 2016).

Stanarević Katavićin ja muiden (2016) tutkimuksessa vastaajan kokemus siitä, että tietoa löytyi hyvin omalla äidinkielellä, oli yhteydessä positiivisempaan kokemukseen sairauden hallinnasta ja ymmärtämisestä. Aktiivinen tiedonhankinta oli yhteydessä huolen tunteeseen, mutta ei kuitenkaan sairauden parempaan ymmärtämiseen tai hallinnan tunteeseen. Vain harva vältteli omaa harvinaissairauttaan koskevaa tietoa. Tiedon välttely oli kuitenkin heikosti, mutta tilastollisesti merkitsevästi yhteydessä vähäisempään hallinnan tunteeseen sekä heikompaan sairauden ymmärtämiseen. Huolen ja tiedon välttelyn välillä ei havaittu keskinäistä suhdetta. Stanarević Katavićin ja muiden (2016) mukaan tutkimustuloksista voidaan päätellä, ettei saatavilla oleva terveystieto ollut riittävää aktiivisesta tiedonhankinnasta huolimatta.

Tiedon puute ja tiedon saannin riittämättömyys lääkäreiltä ovat syitä, jotka ajavat harvinaissairaita hankkimaan tietoa itse. Stanarević Katavić (2019) haastatteli 15 harvinaissairasta selvittäen heidän tyypillistä informaatiokäyttäytymistään ja siihen liittyviä haasteita. Tiedonhankinta oli aktiivisinta diagnoosin saamisen jälkeen, kun taas myöhemmin tietoa hankittiin, mikäli ilmeni uusia oireita, lääkityksiä tai sivuoireita. Myös yleinen kiinnostus omaa harvinaissairautta kohtaan oli syy hakeutua tiedonlähteiden ääreen. Harvinaissairaat kokivat, että oli hankalaa saada tietoa arkielämän tueksi ja lisäksi osa koki, ettei sosiaalisista oikeuksista ollut helppoa löytää tietoa. Myös uuden tutkimustiedon ymmärtäminen ja käyttö oli vaikeaa sen erikoissanaston, saatavuuden tai kielen vuoksi. Osin tästä syystä harvinaissairaat etsivätkin tietoa usein vertaisiltaan, jotka tarjosivat tiedon lisäksi myös henkistä tukea. Myös terveydenhuollon ammattilaiset nähtiin niin tiedonlähteinä kuin poten- 
tiaalisina liittolaisinakin terveystiedon hankinnassa (Stanarević Katavić 2019). Vaikka terveydenhuollon ammattilaiset eivät aina voi toimia parhaana tiedonlähteenä harvinaissairaiden kontekstissa, aikaisemmat tutkimukset osoittavat, että sairastuneet ja heidän läheisensä ovat kokeneet tärkeäksi sen, että ammattilaiset pyrkivät aidosti selvittämään harvinaissairauteen liittyviä seikkoja. Myös ammattilaisten empaattinen asenne potilasta sekä hänen perhettään ja tilannettaan kohtaan on koettu tärkeiksi (Huyard 2009, Grut \& Kvam 2013). Lisäksi terveydenhuollon ammattilaisen tarjoama arkielämää koskeva tieto saattaa kompensoida lääketieteellisen informaation puutetta (Huyard 2009). Mooneyn ja muiden (2013) mukaan myös tiedon jakamisen ajoittaminen oikeaan aikaan on tärkeää, jotta sairastunut pystyy sisäistämään saamaansa tietoa.

Omaan sairauteen liittyvien tekijöiden on osoitettu ohjaavan tiedon hankinnan lisäksi tiedon arviointia. Zhu, Smith, Parrott ja Worthington (2018) saivat tutkimuksessaan selville, että Alfa 1-antitrypsiinin puutostautia (A1AD) sairastavat arvioivat samaa informaatiota eri tavoin taudin vakavuusasteen tai sisällön kiinnostavuuden mukaan. Mikäli vastaajan sairaus ei ollut vaikea, hän koki usein Yhdysvaltain terveysviraston (National Institutes of Health, NIH) verkkosivuston informaation laadukkaammaksi sekä kiinnostavammaksi kuin sellainen vastaaja, jolla sairaus oirehti vakavammin. Verkkosivuston koettu laadukkuus ja kiinnostavuus merkitsi usein sitä, että siitä jaettiin tietoa eteenpäin. Todennäköisemmin sivustosta kerrottiin eteenpäin, mikäli vastaajalla oli hengellinen vakaumus tai hän koki, että sairaus oli vahvasti geneettisesti määräytyvä (Zhu ym. 2018).

\section{Sairautta koskevan tiedon kognitiiviset auktoriteetit}

Harvinaissairaiden käyttämiä tiedonlähteitä ja niiden luotettavuuden arviointiin liittyviä seikkoja on tutkittu vähemmän kuin esimerkiksi harvinaissairaiden tiedontarpeita. Tässä tutkimuksessa tiedonlähteiden luotettavuuden arviointia lähestytään kognitiivisen auktoriteetin käsitteen avulla. Kognitiivinen auktoriteetti (eng. cognitive authority) viittaa uskottavaksi ja luotettavaksi koettuun tiedonlähteeseen, jolla on vaikutusta ajatteluun. Käsitteen taustalla on ajatus kahdesta perustavanlaatuisesti erilaisesta tiedonhankinnan tavasta: ensimmäisen ja toisen käden tiedosta. Ensimmäisen käden tieto koostuu ihmisen omista muistoista ja kokemuksista. Toisen käden tieto sen sijaan on välitteistä, sitä saadaan muilta ihmisiltä. Kognitiiviset auktoriteetit ovat toisen käden tiedonlähteitä, joita pidetään sopivina (eng. proper) ja joiden puoleen käännytään tiedontarpeiden ilmetessä (Wilson 1983). 
Auktoriteettiuskomukset eivät ole muuttumattomia, vaan ne kehittyvät elämän aikana ja ovat myös tilannesidonnaisia. Usein kognitiivisia auktoriteetteja ei tarkoituksellisesti etsitä, vaan käsitykset sopivista tiedonlähteistä rakentuvat osana muuta toimintaa. Joskus kognitiivisia auktoriteetteja on haettava myös tietoisesti (Wilson 1983). Harvinaissairauksien kontekstissa kognitiivisten auktoriteettien etsiminen voi olla tarpeen tiedon puutteesta johtuen.

Tiedonlähteen koettu uskottavuus (eng. credibility) on keskeinen kognitiivisen auktoriteetin elementti. Ollakseen uskottava, tiedonlähteen tulee olla sekä pätevänä pidetty (eng. competent) että luotettava (eng. trustworthy). Lähteen koettu asiantuntemus voi rakentua esimerkiksi kokemuksen, koulutuksen tai maineen varaan. Luotettavuus sen sijaan liittyy käsitykseen tiedonlähteen rehellisyydestä. Kaikki uskottaviksi koetut tiedonlähteet eivät kuitenkaan ole kognitiivisia auktoriteetteja; uskottaviksi koetut tiedonlähteet ovat potentiaalinen joukko kognitiivisia auktoriteetteja (Wilson 1983).

Kognitiivisena auktoriteettina voi toimia paitsi toinen ihminen, myös ammattiryhmä, organisaatio, instituutio, dokumentti tai väline. Auktoriteetin asema rajoittuu tietyn aihepiirin sisälle, vaikka joskus aihepiirin tarkka rajaus on mahdotonta. Muut ihmiset ovatkin arvioijan roolissa siinä, kuinka laajalle tiedonlähteen auktoriteetti ulottuu eri aihepiirien sisällä. Auktoriteettien mielipiteet sekä mahdolliset ohjeet ja neuvot voivat kuitenkin saada painoarvoa myös siinä tapauksessa, ettei varmaa tietoa jostakin asiasta ole olemassa (Wilson 1983).

Aikaisemmissa terveyden kognitiivisia auktoriteetteja käsittelevissä tutkimuksissa on keskitytty erityisesti potilaan ja terveydenhuollon ammattilaisen vuorovaikutukseen ja siihen, miten lääketieteen ja sen edustajien biolääketieteellistä kognitiivista auktoriteettia haastetaan tai täydennetään muilla tietämisen tavoilla (McKenzie 2003, Neal \& McKenzie 2011). Nämä tutkimukset osoittavat, että biolääketieteellistä kognitiivista auktoriteettia haastetaan erityisesti vetoamalla muiden kokemuksiin perustuvaan kokemukselliseen kognitiiviseen auktoriteettiin ja toisaalta omaan päättelyyn, kehollisiin tuntemuksiin tai kokemuksiin perustuvaan henkilökohtaiseen auktoriteettiin (McKenzie 2003, Genuis 2013). Genuisin (2013) tutkimus osoittaa, että potilaat asemoivat itseään eri tavoin sekä suhteessa terveydenhuollon ammattilaisiin että tiedonlähteisiin. Useimmat tutkimukseen osallistuneet kuvasivat itseään itsenäisinä päätöksentekijöinä ja vastuullisina myös tiedonhankinnasta. Tähän asemaan liittyi henkilökohtaisen auktoriteetin korostaminen ja terveydenhuollon ammattilaisten asettaminen oppaan tai konsultin asemaan. Biolääketieteellisen tiedon auktoriteettiasemaa painottaneet potilaat asettivat terveydenhuollon ammattilaiset sekä kognitiivisen auktoriteetin että päätök- 
sentekijän asemaan, jolloin potilaan asema näyttäytyi ammattilaisesta riippuvaisena. Jaettu päätöksenteko potilaan ja terveydenhuollon ammattilaisen välillä sen sijaan ilmensi molemminpuolista arvostusta erityyppiseen tietoon ja kognitiiviseen auktoriteettiin (Genuis 2013). Harvinaissairaiden omaan sairauteen liittyvään tietoon kytkeytyviä kognitiivisia auktoriteetteja ei ole tietojemme mukaan aikaisemmin tutkittu.

\section{Tavoite ja tutkimuskysymykset}

Artikkelissa käsitellään perinnöllisesti harvinaissairaiden suomalaisten aikuisten käsityksiä heidän omasta sairaudestaan ja sitä koskevasta tiedosta. Kiinnostus kohdistuu erityisesti harvinaissairaiden tapaan arvioida omaa sairauttaan koskevien tiedonlähteiden kognitiivista auktoriteettia. Harvinaissairaiden tiedontarpeita on tutkittu jokseenkin paljon, mutta tiedonlähteet ja niiden luotettavuuden arviointi ovat jääneet vähemmälle tarkastelulle. Harvinaissairauksien yhteydessä myös sairauskäsityksiä on tutkittu vain vähän.

Tutkimuskysymykset ovat seuraavat:

1. Millaisia käsityksiä harvinaissairailla on omasta harvinaisesta sairaudestaan?

2. Miten harvinaissairaat arvioivat sairauteen liittyviä tiedonlähteitä ja niiden kognitiivista auktoriteettia?

3. Millainen rooli erilaisilla tiedonlähteillä on sairauskäsityksen muodostumisessa?

\section{Tutkimusmenetelmä}

Tässä luvussa esitetään tutkimuksessa käytetyt tutkimusmenetelmät. Ensin kuvataan aineistonkeruumenetelmään liittyviä seikkoja, jonka jälkeen kuvataan aineiston analyysin eteneminen.

Tutkimuksessa käytettiin laadullista lähestymistapaa. Sillä pyrittiin moniulotteisen todellisen elämän kuvaamiseen sekä ymmärtämiseen ja kohteen kokonaisvaltaiseen tutkimiseen (Hirsjärvi, Remes \& Sajavaara 2009). Koska tarkoituksena oli tuottaa tutkimuskohteesta syvällistä, tarkkaa aineistoa, tutkimuksen osallistujat valittiin harkitusti ja tarkoituksenmukaisesti (Tuomi \& Sarajärvi 2002, Hirsjärvi \& Hurme 2008, Hirsjärvi ym. 2009) edustamaan aiheen parhaiten tuntevia henkilöitä (Tuomi \& Sarajärvi 2002). Koska tutkija oli läheisessä vuorovaikutuksessa osallistujien kanssa, myös tutkimuksen eettisyys korostui (Kylmä \& Juvakka 2007). 


\section{Aineisto}

Tutkimusaineisto kerättiin teemahaastatteluilla, joiden avulla pyrittiin tuomaan esille osallistujien subjektiivisia käsityksiä ja kokemuksia. Haastatteluteemojen suunnittelussa hyödynnettiin tutkimuksen aihetta sivuavaa aikaisempaa tutkimusta. Teemat käsittelivät laajasti informaatiokäyttäytymiseen liittyviä seikkoja (ks. Rotonen 2020, liite 1). Tiedonlähteitä koskevassa teemakokonaisuudessa esille nousivat laajasti harvinaissairaiden käyttämät tiedonlähteet sekä tiedonlähteiden luotettavuuteen liittyvät arviointitavat. Haastatteluissa aiheet olivat jokaiselle haastatellulle samat, mutta kysymysten tarkka muoto ja järjestys vaihtelivat (ks. Hirsjärvi \& Hurme 2008).

Haastateltavat rekrytoitiin Harvinaiset-verkoston avulla. Verkoston yhteyshenkilö jakoi haastattelupyyntöviestiä sähköpostitse verkoston jäsenyhteisöille kahdesti. Jäsenyhteisöt puolestaan jakoivat eteenpäin haastattelupyyntöviestiä omille jäsenilleen. Tutkimukseen osallistui viisi perinnöllisesti harvinaissairasta suomalaista, yli 18-vuotiasta aikuista. Näiden lisäksi yksi henkilö osallistui koehaastatteluun, jonka aineisto jätettiin kuitenkin pois tulosten analysoinnista haastatellun ja haastattelijan läheisen suhteen vuoksi. Haastattelut toteutettiin maalis-kesäkuussa 2019 haastateltavien kotona, opiskelu- tai työpaikalla. Haastattelut kestivät noin 45 minuutista puoleentoista tuntiin. Haastattelut äänitettiin ja litteroitiin tekstimuotoon.

Tutkimuksessa noudatettiin tiukkaa tutkimusetiikkaa, sillä tutkimukseen liittyi arkaluonteisia, terveyteen liittyviä tietoja (Kuula 2011). Jo ennen haastatteluita tehtiin eettistä ennakkoarviointia (Kuula 2011) laatimalla tietosuojailmoitus sekä kertomalla olennaisimmat seikat tutkimuksesta haastateltavien rekrytoimiseen tarkoitetussa viestissä. Osallistujat päättivät itse, osallistuivatko he tutkimukseen ja heidän yksityisyytensä on suojattu raportissa anonymisoinnilla (Kuula 2011). Haastattelut toteutettiin haastatelluiden suullisella suostumuksella. Haastattelujen alussa osallistujille esitettiin tietosuojailmoitus, jossa kerrottiin tutkimukseen liittyvistä seikoista tarkemmin. Näistä seikoista oleellisimmat tuotiin esille myös haastattelutilanteessa kuten se, että haastateltavat voivat keskeyttää tutkimuksessa mukana olemisen milloin tahansa (Tuomi \& Sarajärvi 2002, Hirsjärvi ym. 2009). Aineiston litteroinnin yhteydessä suorat tunnistetiedot poistettiin ja äänitetyt haastattelut tuhottiin litteroinnin jälkeen. Tulokset on anonymisoitu niin, ettei haastatelluista kerrota muuta kuin analyysin kannalta olennaiset taustatiedot. Haastatellut olivat joko työelämässä, opiskelijoita tai eläkkeellä. Tutkimuksen erityispiirre oli, että suurin osa haastatelluista oli jollakin tavalla tekemisissä terveydenhuollon tai sairaanhoidon kanssa koulutuksensa ja/tai työnsä puolesta. 


\section{Aineiston analyysi}

Tutkimuksen analyysimenetelmänä käytettiin teoriasidonnaista sisällönanalyysia, jossa teoreettiset kytkökset toimivat analyysin apuna, mutta aineistolla ei kuitenkaan pyritty testaamaan teoriaa (Tuomi \& Sarajärvi 2002). Sisällönanalyysissa hyödynnettiin teoreettista viitekehystä, joka luotiin aihepiirin esiymmärryksen pohjalta, ja jonka osia Leventhalin ja muiden (2012) sekä Wilsonin (1983) mallit olivat (ks. Rotonen 2020, kuvio 2, s. 24).

Analyysi alkoi litteroidun aineiston tarkalla lukemisella. Tämän jälkeen aineisto ryhmiteltiin ja luokiteltiin merkitsemällä symboleilla teemoihin liittyvät asiat. Luokittelussa hyödynnettiin tutkimuskysymyksiä sekä teemahaastatteluita varten tehtyä runkoa (ks. Rotonen 2020, liite 1). Luokittelun valmistuttua eriteltiin informaatiokäyttäytymiseen liittyvien seikkojen yhteyksiä haastateltujen sairauskäsityksiin.

Tutkimus harvinaissairaiden informaatiokäyttäytymisestä koko laajuudessaan on raportoitu artikkelin ensimmäisen kirjoittajan pro gradu -tutkielmassa (ks. Rotonen 2020). Tässä artikkelissa keskitytään tuloksiin, jotka koskevat harvinaissairaiden käsityksiä heidän omasta sairaudestaan sekä sairautta koskevasta tiedosta keskittyen tiedonlähteiden kognitiiviseen auktoriteettiin.

\section{Tulokset}

Tässä luvussa esitellään tutkimuksen tulokset. Tulokset on jaettu kahteen alalukuun, joista ensimmäisessä käsitellään haastateltujen käsityksiä heidän omasta harvinaissairaudestaan. Toisessa alaluvussa pureudutaan heidän käyttämiinsä ja luottamiinsa tiedonlähteisiin sekä eritellään tiedon ja tiedonlähteiden kytkeytymistä heidän sairauskäsityksiinsä.

\section{Harvinaissairaiden sairauskäsitykset}

Kaikilla haastatelluilla oli eri harvinaissairaus. Osalla heistä sairaus oli esiintynyt aiemmin suvussa, mutta ei kaikilla. Joillakin sairaus oli ilmennyt jo varhain lapsuudessa, toisilla vasta myöhemmin aikuisiällä. Haastateltavat olivatkin eri vaiheissa sairauden aikajanaa. Sairauden aikajana oli merkityksellinen sekä sairauden hyväksymisen että sairausidentiteetin kehittymisen näkökulmasta. Mitä pidempi aika sairauden ilmenemisestä oli, sitä paremmin harvinaissairaus oli hyväksytty osaksi elämää. Toisaalta myös silloin, kun sairaus oli ilmennyt jo lapsuudessa, elämässä oli voinut olla hetkiä, jolloin sairauden hyväksyminen oli ollut vaikeaa. Mikäli sairaus oli ilmennyt vasta 
aikuisiällä, sairauden kanssa elämiseen sopeutuminen saattoi olla vielä osin kesken. Sairauden ilmenemisajankohdasta riippumatta kaikki haastatellut pyrkivät mahdollisimman hyvään arkielämään sairaudesta huolimatta.

Sairauden syyksi koettiin useimmiten sen perinnöllisyys, vaikka joskus oli voitu epäillä perinnöllisyydestä poikkeavaakin syytä. Esille tuli kuitenkin myös kohtalon uskoon verrattava kokemus, jolloin oma harvinaissairaus koettiin oman elämän haasteena:

"[E]nnen syntymää mää oon valinnu haasteet tähän elämään... että en nyt sit tiedä mikä se on oikeesti, mutta se on kiva ajatus. Et se [sairaus] on tavallaan... mun... valitsema eikä jonku muun" (H2).

Kaikki haastatellut harvinaissairaat olivat kokeneet sairaudestaan johtuvia fyysisiä seurauksia, tyypillisimmin fyysisiä rajoitteita. Lisäksi seuraukset saattoivat olla psyykkisiä. Tällaiset seuraukset liittyivät muun muassa tulevaisuuden pohtimiseen ja emotionaaliseen ahdinkoon, mutta myös esimerkiksi normaalien ruumiintoimintojen arvostaminen nousi esille. Fyysisten ja psyykkisten seurausten lisäksi tuli esille taloudellisia, sosiaalisia, ammatinvalintaan ja uusien taitojen opetteluun liittyviä seurauksia. Nämä seuraukset saattoivat olla joko kielteisiä tai myönteisiä.

Haastatellut kokivat useimmiten ainakin jonkin asteista hallintaa omasta harvinaissairaudestaan.

"[K]yllä mä ainaki pystyn niinku kampoihin pistämään, mutta että kyllähän se... jossain vaiheessa iän myötä... alaspäin siinä niinku suunta, mutta niin se on ihmisillä muutenkin" ( $\left.\mathrm{H}_{5}\right)$.

Esille nousi myös kokemus siitä, ettei omaa sairautta voinut hallita itse millään tavalla. Sairauden hallinnan yhteydessä tuli selkeästi ilmi eri harvinaissairauksien aiheuttamat erityyppiset oireet ja se, oliko oireisiin olemassa tehokasta hoitokeinoa. Mikäli hallintaa koettiin olevan edes jonkin verran, sairauden hallintakeinot liittyivät usein omaan toimintaan, erityisesti liikuntaan.

\section{Sairautta koskeva tieto ja kognitiiviset auktoriteetit}

Haastatteluissa korostui yhtäältä lääketieteellisen tiedon kognitiivinen auktoriteetti ja toisaalta henkilökohtainen auktoriteetti eli ensikäden tieto. Myös vertaiset olivat luotettuja tiedonlähteitä erityisesti kokemustiedon yhteydessä. Tiedonlähteiden luotettavuuden arviointitavoissa oli havaittavissa eroavaisuuksia niin tiedon tyypin (esimerkiksi asiantuntijatieto tai vertaistieto) kuin tiedon arvioijan koulutustaustan ja kokemuksen perusteella. 


\section{Asiantuntijatieto}

Haastatellut harvinaissairaat käyttivät paljolti digitaalisia tiedonlähteitä. Lähes kaikki haastatelluista käyttivät lääketieteellisiä tietokantoja, joista he lukivat lääketieteellisiä julkaisuja. Koulutus tai työ terveydenhuollon tai sairaanhoidon parissa auttoi ymmärtämään lääketieteen termistöä ja näin lukemaan lääketieteellisiä tutkimuksia. Koska merkittävä osa harvinaissairauksiin liittyvästä tutkimustiedosta oli englanninkielistä, kielitaito korostui.

"[J]os lähtee lukee niitä [tieteellisiä artikkeleita]... englannin kielistä erittäin raskasta tekstiä jos siihen ei oo perehtyny... niin siinä niinku kestää monta päivää ku niitä lukee" (H1).

Lisäksi käytettyjen ja luotettujen digitaalisten tiedonlähteiden joukkoon lukeutui terveydenhuoltoalan virallisten toimijoiden ylläpitämiä sivustoja sekä harvinaissairauksiin keskittyvien organisaatioiden sivustoja:

”Tämmöset... viralliset tietokannat. Niinkö vaikka, että googlettamalla löytyy esimerkiksi... harvinaisten sairauksien rekisteri... tai siis tietokanta, niin se on kyllä semmonen, että siihen pystyy aika paljon luottaa" ( $\left.\mathrm{H}_{3}\right)$.

Näiden lisäksi luotettavaksi tiedontarjoajaksi koettiin eri harvinaissairauksiin keskittyvät järjestöt, liitot tai yhdistykset, jotka olivat usein kolmannen sektorin toimijoita. Näiden toimijoiden kautta saatettiin saada tietoa esimerkiksi uusista hoitokeinoista. Myös toimijoiden sosiaalisesta mediasta voitiin seurata passiivisesti uutta tutkimustietoa:

"[Sosiaalisen median] kautta se [harvinaissairauteen liittyvä organisaatio]... tavallaan niinku vinkkaa et hei nyt on tullu tämmönen tutkimus tähän liittyen, että käykää kattoo" (H5).

Harvinaissairauksiin keskittyviä organisaatioita hyödynsivät omassa tiedonhankinnassaan aktiivisesti erityisesti ne haastateltavat, joiden oma koulutus ei liittynyt terveydenhuoltoon tai sairaanhoitoon.

"Sitte vaikka... jos on tulossa jotain uusia [hoitokeinoja], niin sitte niistä tietää yleensä ensimmäiseksi tuolta [harvinaissairauksiin liittyvältä organisaatiolta]" (H2).

Haastatellulla saattoi olla näiden organisaatioiden edustajiin henkilökohtaisia sosiaalisia suhteita, jolloin heitä oli helppoa käyttää tiedonlähteenä:

"[J]os hakee just jotain eksaktia... niin kyl mää sitte haen sitä esimerkiks jonkun [organisaation] nettisivuilta suoraan... sitte jos mullon vaan yhteystiedot, niin mä mielummin ehkä kysyn" (H4).

Tiedonlähteiden luotettavuutta arvioitiin sen mukaan, millaista tietoa käsiteltiin. Lääketieteellisen tai muun asiantuntijatiedon luotettavuuden arviointia kuvattiin suurelta osin ulkoisiin ja tekstimuodollisiin seikkoihin kuten tekijyyteen, ajantasaisuuteen, oikeakielisyyteen sekä lähdemerkintöihin tai 
viittauksiin vedoten. Samalla saatettiin tarkastella myös tiedonlähteen objektiivisuutta.

"[M]itä enemmän mainoksia internet-sivulla on, niin sitä vähemmän luottaa... ja tota onko siinä viitteitä ja myös niinku jos on jotain kuvituskuvia, niin se saattaa viedä sitä epäluotettavampaan suuntaan" (H3).

Myös lääketieteellinen todistaminen koettiin luotettavuuden osoittajaksi:

"[S]emmonen se lähtökohta on, että... siellä täytyy olla sitä tutkimusnäyttöö... et se ei oo vaan mututietoo" ( $\left.\mathrm{H}_{5}\right)$.

Monet näistä arvioinnin tavoista osoittivat, että haastateltujen harvinaissairaiden valmiudet arvioida tiedonlähteitä olivat hyvin kehittyneet. Tämän osoitti myös se, että haastateltavat saattoivat pohtia miten tutkimustiedon tuottamisen tapa vaikuttaa tiedon tulkintatapoihin:

"[J]os sitte on niinku tutkimuksia niin täytyy niinku muistaa että... et sä pystys vaikka tapaustutkimusta samallailla yleistää ku se että jos on niinko isompi aineisto" ( $\left.\mathrm{H}_{5}\right)$.

Toisaalta myös jonkinlainen intuitio asiantuntijatiedon luotettavuudessa tuli ilmi. Tähän saattoi yhdistyä koulutustausta ja tottumus tiedonhankintaan:

"Kyllä mää koen, että se on aika helppoa [arvioida tiedonlähteiden luotettavuutta], koska sitä joutuu tekemään omassa työssäki koko ajan. Niin se on aika semmonen ... alitajuisesti tapahtuva prosessi... koulutus on tehny tehtäzänsä" $\left(\mathrm{H}_{3}\right)$.

Asiantuntijatiedon luotettavuuden arvioinnissa nousi esille mielenkiintoinen tulos, joka on oleellinen harvinaissairauksien kontekstissa. Tämä oli harvinaissairauksien marginaalisuus:

"[J]os se on ollu tämmönen joku ihan lääketieteellinen julkasu, niin mä oon aatellu, et kyl tän nyt täytyy olla ihan luotettavaa... Tuskimpa kukaan huvikseen lähtee tutkimaan [harvinaissairauksia] niin tota mä oon aatellu tavallaan ne ketkä niinku tutkii näitä ja julkasee jotain, niin ne on varmaan ihan tosissaan... koska se on aika pieni piiri tutkijoita varmaan... ketkä tekee tämmöstä tutkimusta" (H1).

Harvinaissairauksien marginaalisuuden voidaan tulkita lisäävän luottamusta aihetta koskeviin tiedonlähteisiin. Harvinaissairauksiin liittyvän yhteisön marginaalisuus on tullut esille myös Springin (2014b) tutkimuksessa.

Terveydenhuollon ammattilaisten kohdalla empaattisuus harvinaissairasta ja tämän tilannetta kohtaan herätti luottamusta. Ammattilaisen asiantuntijuuden lisäksi tärkeää oli kokemus rehellisyydestä: ammattilaisen odotettiin tarkistavan sellaiset asiat, jotka olivat hänelle vieraita.

"[L]ääkrïi... tuottaa enemmän luottamusta... et sanoo että "mä en tiäkkö tässä vaiheessa tiedä, mutta mä otan tästä asiasta selvää ja kerron sulle sitte myöhem- 
min" ku semmonen, että alkaa sitte ympäripyöreesti selittää jotain asiaa, jossa ei oo mitään sisältöä" (H2).

Luottamusta terveydenhuollon ammattilaisiin saattoi horjuttaa ammattilaisen epäasiallinen ja epäempaattinen potilaan kohtelu. Eräs haastateltu kertoi lääkärin epäasiallisista kommenteista diagnoosin saamisen yhteydessä, mikä oli vaikuttanut lääkäriltä saadun tiedon torjumiseen ja näin myös hoidon viivästymiseen:

"[S]e oli sit se sama lääkäri, joka mulle eka sitä [toimenpidettä] ehdotti, ja mä olin että... mä en sulta ota niinku yhtään mitään... se vaikutti siihenkin, että mä en niin kun edes niin ajoissa mennyt siihen [toimenpiteeseen] kun olis voinu" (H4).

Toisaalta hyvät kokemukset terveydenhuollon parissa lisäsivät luottamusta ammattilaisia kohtaan:

"[S]illon oli ollu fiksu... lääkäri... ja ohjannu... [sairaalaan] ja sielt on sitte

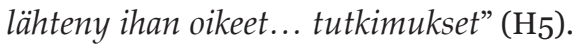

Terveydenhuollosta saadut hyvät tai huonot kokemukset olivat siis osin kytköksissä siihen, saivatko terveydenhuollon ammattilaiset, erityisesti lääkärit, kognitiivisen auktoriteetin aseman. Huonot kokemukset terveydenhuollon parissa ja näin myös luottamuksen puute lääkäreitä kohtaan saattoivat heikentää heidän auktoriteettiasemaansa. Tällöin kognitiivisen auktoriteetin aseman saattoivat saada muut, terveydenhuollon ulkopuoliset lähteet, esimerkiksi aihepiirin tutkijat tai vertaiset.

Haastatellun omaan koulutukseen ja työkokemukseen nojaava asiantuntemus tuli vahvasti esille lähteiden luotettavuuden arvioinnissa erityisesti lääketieteellisen ja asiantuntijatiedon kohdalla. Erityisesti tämä ilmeni äärimmäisten vaihtoehtoisten hoitokeinojen yhteydessä.

"No mä en luota niihin yhtään... ehkä tän koulutuksenki takia tämmösistä vaihtoehtosista vastaan tosi paljon" (H1).

"[T]ässäki ehkä se ammatti... nousee aika... paljon" ( $\left.\mathrm{H}_{3}\right)$.

Äärimmäiset vaihtoehtoiset hoitokeinot eivät herättäneet luottamusta yhdessäkään haastatellussa koulutus- tai työtaustasta riippumatta. Tämä oli myös vahva osoitus lääketieteellisen tiedon vahvasta auktoriteetista. Usein ilmeni kuitenkin mielenkiintoa kevyempiin vaihtoehtoisiin hoitokeinoihin, mutta niidenkin yhteydessä nousi esille lääketieteellisen tiedon kognitiivinen auktoriteetti.

"[S]iitäkihän [akupunktiosta] alakaa olla jo tutkimustietoa, että monilla se auttaa" ( $\left.\mathrm{H}_{5}\right)$.

"[J]onku verran [on käyttänyt vaihtoehtoisia hoitokeinoja]... Sillain toissijasesti... sitte tarkistaa... tarkkaan kaikki aines- 
osat, että niissä ei nyt varmasti oo mikään mikä clashais niin kun nuitten [lääketieteellisten hoitojen] kanssa" (H2).

Osin luottamuksen puute vaihtoehtoisiin hoitokeinoihin liittyi haastatellun koulutukselliseen tai ammatilliseen taustaan terveydenhuolto- tai sairaanhoitoalalla, mutta tämä ei selittänyt kaikkien haastateltujen suhtautumista äärimmäisiin vaihtoehtoisiin hoitokeinoihin. Kevyempiin ja mahdollisesti vielä lääketieteellistä todistusta saaneisiin hoitokeinoihin sen sijaan oli luottamusta.

\section{Oma kokemus ja asiantuntijuus}

Asiantuntijatiedon lisäksi haastatteluissa korostui oman kokemuksen ja asiantuntijuuden merkitys tiedonlähteenä. Oman kokemuksen kautta saatu tieto saattoi koskea esimerkiksi jonkin apuvälineen käyttöä:

"[M]un mielestä [on] parasta kun pääsee testaamaan ja ite kokeilemaan jotaki ja sitten keskustelemaan [tuotteista sen asiantuntijan kanssa]" (H4).

Omalla kokemuksella saattoi myös verifioida muualta saatua tietoa:

"Että kun luki kaikki ne oirekuvat... mitä on tehty [kyseistä harvinaissairautta] sairastaville, niin sitte pysty vertaamaan, että mulle on tehty nuo samat jutut... sitte tietysti jos mennään ihan näihin tieteellisiin artikkeleihin, niin tapausselostuksia on... niin siinä pysty aika hyvin vertaamaan sitte itteensä" ( $\left.\mathrm{H}_{3}\right)$.

Omia kokemuksia jostakin hoidosta saatettiin myös verrata muiden kokemuksiin, joita löytyi esimerkiksi internetin kautta:

"[K]yl joitaki pystyy [vertaamaan omiin kokemuksiin]... et mitä ite on kokenu [hoidosta], ni sit kattoo... miten se [hoito] pitäs vaikuttaa" (H1).

Mikäli lääkäri ei pystynyt tarjoamaan harvinaissairaalle hänen tarvitsemaansa tietoa, joutui tiedon hankkimaan itse muista tiedonlähteistä, mikä osoitti myös aktiivisuutta oman sairauden hoitoon ja elämänhallintaan:

“[E]tenki ku oli... lääkäri, joka oli huono kokemus... niin sitte joutu kääntymään juuri internetiin sen vuoksi” (H2).

Aktiivisuus tiedonhankinnassa oli lisääntynyt, mikäli terveydenhuollosta saatu tieto oli vähäistä tai muuten riittämätöntä:

"[I]han alussa luotti, et kyllä ne lääkärit tietää... Sillon ei ehkä ettiny niin paljon tietoa, mut... ku on huomannu, ettei ne lääkärit tiedäkää, ni sit on yrittäny ite ettiä... mahollisesti vielä lisää tietoo" (H1).

Tässä yhteydessä tuli esille, että tärkeiksi koetut tiedonlähteet olivat muuttuneet sairauden aikana. Samalla oma asiantuntijuus ja kokemus omasta sairaudesta kasvoi. 
Tiedonlähteiden luotettavuuden arviointi koettiin usein melko helpoksi; jo olemassa oleva oma tieto antoi myös vankan pohjan tiedonlähteiden luotettavuuden arvioinnille.

“[S]iin on kyl jonkun näkönen intuitio... minkä sä klikkaat auki ja lähet lukemaan... Mut en mä osaa sanoo... jos on ihan tuntemattomia linkkejä siinä tai tällasia, niin mikä se on sitte se, miksi sä juuri sinne menet ja miksi sä uskot siihen tietoon. Kyl se yhdistyy niin paljon kaikkeen muuhun mitä sul on jo päässä sitä tietoo. Sitä uutta tietoo vaan yhdistelee kaikkeen aikasempaan mitä on ja... sit se joko on todennäkösesti totta tai sit se ei ole" ( $\left.\mathrm{H}_{4}\right)$.

Tässäkin korostui haastateltujen asiantuntijuus ja kokemukset omasta sairaudesta. Harvinaissairas saattoi kokea oman asiantuntijuutensa olevan niin kehittynyttä, että hän luotti itseensä arvioidessaan omaa sairauttaan koskevan tiedon ja tiedonlähteiden luotettavuutta. Myös harhaanjohtavan tai väärän tiedon kohtaaminen osoitti omaa asiantuntijuutta, sillä tällaista tietoa kohdatessa se oli useimmiten tunnistettu vääräksi tai harhaanjohtavaksi.

Painetut lähteet eivät osoittautuneet merkittäviksi tiedonlähteiksi harvinaissairaille. Ennen kuin digitaaliset tiedonlähteet olivat yhtä merkittäviä tiedonlähteitä kuin nykyään, osa haastatelluista oli saattanut etsiä perustietoa omasta sairaudestaan kirjoista. Nykyään painetuista lähteistä, lähinnä lehdistä, oli saatettu löytää omaa harvinaissairautta sivuavaa tietoa lähinnä passiivisen tiedonhankinnan kautta, mikä oli johtanut myös tarkempaan tiedonhankintaan. Sattumalta saadut tiedot myös tarkistettiin usein muista tiedonlähteistä.

"[S]itä ei pidä vähätellä, koska [iltapäivälehdessä] oli juttua [eräästä hoitokeinosta]... sit rupesit googlettaa lisää niin se oli ihan täyttä asiaa mitä siel oli” (H1). Myös muista tiedonlähteistä hankittua tietoa saatettiin verifioida eri lähteitä käyttämällä:

"[K]yl sen huomas myös sitte kun googlaa ja kattoo vähän eri paikkoja, niin suhtautuu joihinkin paikkoihin varauksella ja joihinki sitte vähän luottaa enemmän. Ja myös huomaa sen, että siellä on erojaki siinä että... se ei oo ihan samanlainen se tieto kaikissa" (H3).

\section{Vertaistieto}

Myös vertaisilta haettiin tietoa. He olivatkin osalle haastatelluista yksi tärkeimmistä tiedonlähteistä.

"[E]hkä sen tyyppisissä [esimerkiksi jokin vaikea oire] tulee niinku lähettyä hakee myös sitä, että... tietääkö joku muu, kun ei nämä [terveydenhuollon ammattilaiset] tiiä" ( $\left.\mathrm{H}_{5}\right)$. 
Vertaisten asema auktoriteetteina erityisesti kokemustiedon ja arkielämää tukevien käytännönläheisten vinkkien osalta voidaankin päätellä johtuvan osin tiedon puutteesta. Usein vertaistietoa etsittiin internetin kautta, esimerkiksi sosiaalisen median vertaistukiryhmistä tai blogeista. Joskus vertaiset, joilta haettiin tietoa, olivat ulkomaalaisia, jolloin englanninkielentaito korostui. Myös oma sosiaalinen verkosto saattoi olla tärkeä tiedonlähde, johon lukeutui niin vertaisia kuin harvinaissairauden asiantuntijoitakin:

"[M]ä en aktiivisesti oikeestaan itse etsi sitä yhtään, vaan se tieto tulee kyllä sieltä [omasta sosiaalisesta verkostosta] mulle" ( $\left.\mathrm{H}_{4}\right)$.

Vertaistiedon kohdalla tärkeimmiksi luotettavuuden kriteereiksi muodostuivat niin oma kuin vertaistenkin kokemus ja asiantuntijuus harvinaisesta sairaudesta.

"Vakavissa asioissa mää en luota muihin ihmisiin [kuin lääkäreihin] siinä mielessä just ku on niinku niin erilaiset yksilökokemukset... käytännön asioissa, niihin on helppo luottaa kun he [vertaiset] itse elävät sitä elämää nii näkee sen käytännössä" (H2).

Jos vertaisilta haettiin vinkkejä esimerkiksi johonkin oireeseen tai yleisemmin arkielämän tueksi sairauden kanssa, arkijärki ja omat sekä vertaisten arvomaailmat tai asenteet saattoivat vaikuttaa siihen, pidettiinkö vertaisen jakamaa kokemustietoa luotettavana:

"[J]os siinä on joku niinku ymmärrettävissä oleva mekanismi miksi tämä asia voisi toimia näin... Tai että jos se niinku toistuu vaikka useamman vertaisen kohalla... joissaki asioissa... mä mietin että, että no ei oo tietoo auttaako tää, mutta voiko tästä olla jotaki [terveydellistä] haittaa. Ja jos siitä ei oo mitään haittaa, niin ihan sama kokeilla" ( $\left.\mathrm{H}_{5}\right)$.

"Se [luotettavuuden arviointi] on ollu helppoo, että... siitä aika nopeesti näkee... minkälainen suhtautuminen heillä [vertaisilla] on siihen sairauteen ja sit sen pohjalta pystyy... arvioimaan, että onko sitte muukaan tieto niinku ajan tasalla tai luotettavaa" (H2).

Vertaistiedon kohdalla tuli ilmi myös lääketieteellisen tiedon kognitiivinen auktoriteetti, mikäli vertaisen vinkit olivat lääkärin määräämien hoitomuotojen vastaisia.

\section{Tiedonlähteet ja sairauskäsitys}

Harvinaissairaiden käsitykset heidän omasta sairaudestaan tulivat esille heidän käyttämissään tiedonlähteissä ja kognitiivisissa auktoriteeteissa sairauden hallinnan, sairauden aikajanan sekä sairausidentiteetin yhteydessä. Sairauden syistä ja seurauksista keskusteltaessa tiedonlähteiden merkitys sen sijaan näyttäytyi vähäisempänä. 
Pyrkimykset sairauden hallintaan ilmenivät tavoissa hankkia ja käyttää tiedonlähteitä tai tietoa. Asiantuntijatiedon kohdalla molemminpuolinen vuorovaikutus terveydenhuollon ammattilaisen kanssa osoitti pyrkimystä hallita omaa harvinaissairautta. Itse hankittua tietoa saatettiin jakaa esimerkiksi lääkärille, mikä ilmeni pyrkimyksenä sairauden hallintaan:

"[K]yl tää menee enemmänki sillain päin, että ite ettii sieltä Googlesta, sit menee lääkäriin... ehdottamaan jotain” (H1).

Terveydenhuollon ammattilaisen keskeinen rooli tiedonlähteenä ja yhteys sairauden hallintaan ilmeni erityisesti tapauksissa, joissa sairaus aiheutti paljon tai vakavia oireita. Tällöin osavastuu sairauden hallinnasta koettiin olevan terveydenhuollon ammattilaisilla, jolloin myös terveydenhuollon asiantuntijoiden kognitiivinen auktoriteetti korostui.

"Heidän [lääkäreiden] niin kun tulisi osata... antaa neuvoja just semmosissa tilanteissa ku... [on oireita]... ja jos ei entuudestaan tiedä näitä asioita niin sitte kysyä joltaki, joka tietää tai ettiä netistä tai mistä nyt lääkärit ettiikään asioita" (H2).

Tiedonlähteenä myös harvinaissairauksiin perehtyneillä organisaatioilla saattoi olla suuri merkitys elämänhallinnassa (vrt. Savolainen 2008), mikä heijastui välillisesti myös sairauden hallintaan:

"[J]os ei ois... mitenkään niin kun yhteydessä siihen [organisaatioon], niin sitte... ois aika sillain ö aapisen reunassa, että no mitä mää nyt ite voin vaikuttaa vaikka [sairaudesta johtuviin, arjessa tarvittaviin asioihin]" (H2).

Toisaalta myös oma asiantuntijuus korostui, kun omaa jo olemassa olevaa tietoa käytettiin oman sairauden hallintaan:

"[S]e on... aika paljon semmosta... perustietoo jonka mä oon tienny jo lapsesta asti" ( $\left.\mathrm{H}_{5}\right)$.

Mikäli sairaus oli ilmennyt jo lapsuudessa, tietoa oli saatu usein jo vanhemmilta, mikä puolestaan oli edistänyt vankan pohjatiedon rakentumista. Lisäksi vertaisilta saatavat käytännön vinkit sekä kokemustieto olivat tärkeitä sairauden hallinnalle. Aina tietoa ei ollut kuitenkaan helppo saada yksilöllisen taudinkuvan tai yksinkertaisesti vertaisten puutteen vuoksi: "[L]ähinnä se on sillain, että huomaa että jollaki on ollu blogi aiheesta... ja sitten mää otan siihen yhteyttä, että hei onko sulla vinkkejä vaikka [arkeen liittyviin, hyvinvointia edistäviin asioihin]" (H2).

Sairauden aikajana ilmeni kulloinkin käytetyissä tiedonlähteissä. Tärkeiksi koetut tiedonlähteet saattoivat muuttua sairauden aikana ja sairausidentiteetin kehittyessä, mikä ilmentää tiedonlähteiden vaihtelevaa roolia sairauden aikajanalla. Esimerkiksi vertaistiedon tärkeyden korostuminen sairauden myöhemmässä vaiheessa tuli esille: 
"[S]e ihmisten auktoriteettiusko on niin vahva, että... jos sä nyt saat diagnoosin, niin kyllä ehkä siinä vaihees tärkeintä on saada jutella sen lääkärin kanssa, joka, kuvittelis et se on niinku auktoriteettiasteikolla siel ylhääl. Kun taas sitten ne vuosikausia sen diagnoosin kanssa eläneet, niin... niitten tärkeys nousee sit vähitellen sieltä, että... se lääkäri kertoo vaan sellasta yleistä ja muuta, mut sitte se, kultakin [vertaiselta] sä saat sellasen eksaktin tarinan sieltä hänen elämästään” ( $\left.\mathrm{H}_{4}\right)$.

Sairauden aikajanalla ilmeni myös tiedon yhdistelyä ensimmäisen ja toisen käden tiedonlähteistä. Tämä helpotti tiedon ja tiedonlähteiden luotettavuuden arviointia, sillä itselle sopivimmat ja luotetuimmat tiedonlähteet, kognitiiviset auktoriteetit, olivat vakiintuneet ajan myötä. Ajan myötä karttunut tieto helpotti myös eri tiedonlähteiden verifiointia:

“[M]ä googlaan sen vähintään suomeksi ja englanniksi ja... [erään hoitotavan] kohdalla huomattiin [riski]... ja se oli niin tuore tieto, ettei siitä löytyny mistään mitään. No sit mä soitin suoraan sille [aiheen asiantuntijalle]... Tai niinku sitte ku tulee [tietynlaisia tutkimuksia]... niin niitä täytyy sit ettiä tuolt aina. Ja se on sit aina ku menee tonne englanninkieliseen maailmaan, nii... siitä pitää niinku suodattaa se oikee tieto sieltä, että on vähitellen nyt löytyny ne tietyt kanavat mitä sitten enemmän lukee" ( $\left.\mathrm{H}_{4}\right)$.

Myös sairauden kesto oli osin yhteydessä siihen, millaisia tiedonlähteitä käytettiin: kun sairaus oli ilmennyt jo varhaislapsuudessa, käytetyt tiedonlähteet olivat vakiintuneempia kuin silloin, kun sairaus oli ilmennyt aikuisiällä.

Tiedonhankinnan aktiivisuus saattoi kasvaa, mikäli oli huomattu, ettei terveydenhuollon ammattilaisilta saanut tarpeeksi tietoa, jolloin muita tiedonlähteitä oli etsitty itsenäisesti. Stanarević Katavić (2019) sai selville tutkimuksessaan, että tietoa hankittiin aktiivisimmin diagnoosin saamisen jälkeen, kun taas myöhemmässä sairauden vaiheessa tietoa haettiin uusien oireiden tai lääkitysten yhteydessä. Tämä näkyi myös tämän tutkimuksen tuloksissa, mutta usein tietoa haettiin aktiivisesti jo ennen diagnoosin saamista:

"[S]iis kirjastot oli sellanen, että mä siis hain kirjoista sitä tietoo... mä niinku tiesin oikeesti et mullon tämä... [harvinaissairaus], vaikkei sitä oltukaan tutkittu missään" ( $\left.\mathrm{H}_{4}\right)$.

Sairausidentiteetin muotoutuminen ilmeni käytetyissä tiedonlähteissä. Tiedon yhdistely omista kokemuksista, itsellä jo olemassa olevasta tiedosta ja ulkoisista tiedonlähteistä ilmeni sairausidentiteetin muotoutumisessa sekä sairauden aikajanalla sairauden edetessä.

"[S]e tieto on niinku vähitellen kertynyt" $\left(\mathrm{H}_{4}\right)$.

"No mää oon itse asiassa niinku aina... varmaan vähän ripotellen hankkinuki sitä tietoo" ( $\left.\mathrm{H}_{5}\right)$. 
Tiedon yhdistely auttoi rakentamaan harvinaisesta sairaudesta monipuolisen kuvan, mikä vaikutti sairausidentiteetin muotoutumiseen sairauden eri aikoina. Omien kokemusten vertaaminen muiden kokemuksiin sekä vertaisten tapaaminen ylipäätään saattoi auttaa haastateltua kehittämään tai vahvistamaan omaa sairausidentiteettiä:

"[E]t se oikea tieto siitä minkälaista elämä on [jotakin sairautta sairastavalla]... nii se tulee oikeesti vasta tapaamalla [vertaisia]... Ja siihen on pystyny hirveesti peilaamaan sitte omaa [tilannetta]" ( $\left.\mathrm{H}_{4}\right)$.

Erityisesti tiedonlähteistä saatu uusi tieto muokkasi sairausidentiteettiä, mikäli se muutti käsitystä omasta sairaudesta. Tällainen tieto saattoi liittyä esimerkiksi lapsena saatuun, myöhemmin vääräksi osoittautuneeseen diagnoosiin:

"[Oli] tavallaan jouduttu vaan keksimään [diagnoosi]... että tää vois olla tää, mutta sitte... tämä ei tule jäämään lopulliseksi diagnoosiksi ja sitte "aijaa" ja sit mä lähin sitä niinku selvittämään uuestaan" (H3).

Tieto oli aktivoinut haastatellun hankkimaan itsenäisesti tietoa muista mahdollisista diagnooseista. Lisäksi tuli esille terveydenhuollon ammattilaisen potentiaalinen vaikutus sairausidentiteetin kehittymiseen ja toisaalta myös sairauden aikajanaan: mikäli ammattilainen olisi toiminut tiedonlähteenä haastatellulle harvinaissairaalle jo sairauden varhaisessa vaiheessa, tällä olisi saattanut olla merkitystä positiivisemman sairausidentiteetin muodostumiseen.

"Mulle ois ollu hyötyä, jos olis ollu sellanen perheen ulkopuolinen ihminen, joka olis keskustellut mun kans siitä... Elikkä se ois tarkottanu kyl lähinnä ny lääkäreitä. Että ois ollu oikeesti aikaa... vastata mun kysymyksiin ja mun pelkoihin" ( $\left.\mathrm{H}_{4}\right)$.

Tällöin myös sairauden hyväksyminen sairauden varhaisemmassa vaiheessa olisi voinut helpottua. Kun haastateltu ei ollut vielä hyväksynyt sairautta osaksi elämäänsä, hän ei ollut myöskään halukas ottamaan vastaan tai hankkimaan sairauteensa liittyvää tietoa. Ajan myötä sairauden hyväksyminen herätti kuitenkin kiinnostuksen tätä tietoa kohtaan. Asenteen muutoksella oli siis myös merkitystä positiivisemman sairausidentiteetin muodostumiselle.

\section{Pohdinta ja johtopäätökset}

Tutkimuksessa tarkasteltiin aikuisten harvinaissairaiden käsityksiä heidän omasta sairaudestaan ja sitä koskevasta tiedosta sekä tiedonlähteiden luotettavuudesta. Huomio kohdentui Leventhalin ja tutkijakollegoiden (2012) esittämän sairauskäsityksen viiden ulottuvuuden (aikajana, seuraukset, syyt, 
hallinta, sairausidentiteetti) identifiointiin sekä sairautta koskevien tiedonlähteiden kognitiivisen auktoriteetin erittelyyn. Tuloksissa sairauden hallinta ja aikajana sekä sairausidentiteetti nousivat keskeisiksi tiedonlähteistä ja niiden kognitiivisesta auktoriteetista keskusteltaessa.

Erilaiset tiedontarpeet sairauden eri vaiheissa ohjasivat erilaisten kognitiivisten auktoriteettien pariin. Tiedontarpeissa painottuivat lääketieteelliset kysymykset ja uusi tutkimus, ja tuloksissa korostuikin erityisesti lääketieteellisen tiedon kognitiivinen auktoriteetti. Tiedonlähteen luotettavuuden arviointi pohjautui erilaisiin kriteereihin käytetystä tiedonlähteestä riippuen. Kriteerit olivat suurelta osin sellaisia, jotka ovat ominaisia myös muunlaisessa tiedon arvioinnissa. Lääketieteellisen tiedon pätevyyttä arvioitiin esimerkiksi tekijyyden, ajantasaisuuden, oikeakielisyyden ja viittausten perusteella sekä tarkastelemalla lähteen objektiivisuutta. Lisäksi esille nousi erityisesti harvinaissairauksiin liittyvä tiedonlähteen luotettavuuden arviointiin vaikuttava seikka: aihepiirin marginaalisuus. Luottamusta terveydenhuollon ammattilaisiin lisäsi heidän empaattinen asenteensa harvinaissairasta ja tämän tilannetta kohtaan. Luottamusta herätti myös rohkeus tunnustaa asiantuntemuksen puute ja pyrkimys selvittää asiaa eteenpäin. Terveydenhuollon ammattilaisten empaattisuuden merkitys on noussut esille myös aikaisemmissa tutkimuksissa (Huyard 2009, Grut \& Kvam 2013, Stanarević Katavić 2019). Huomiot tukevat Wilsonin (1983) väitettä siitä, että ollakseen uskottava, tiedonlähteen tulee olla paitsi pätevä, myös luotettava. Aihepiirin tutkijat ja lääkärit korostuivat vahvoina kognitiivisina auktoriteetteina tämän tutkielman yhteydessä mahdollisesti siksi, että useimmat haastatelluista harvinaissairaista toimivat koulutuksellisesti tai ammatillisesti jollakin tavalla terveydenhuolto- tai sairaanhoitoalan parissa. Myös olemassa olevan tiedon vähäisyys ja tiedon merkitys epävarmuuden vähentämiseksi voidaan nähdä lääketieteellisen auktoriteetin korostumisen vaikuttimina tässä harvinaissairauksien kontekstissa.

Lääketieteellisen kognitiivisen auktoriteetin lisäksi henkilökohtainen kognitiivinen auktoriteetti tuli vahvasti ilmi. Terveydenhuollosta saadun tiedon riittämättömyyden sekä kirjallisuuden ja asiantuntijoiden puutteen vuoksi harvinaissairaiden oma asiantuntemus samoin kuin harvinaissairaiden läheistenkin asema tiedonlähteenä korostuu harvinaisten sairauksien kontekstissa, kuten myös Springin (2014b) tutkimus on osoittanut. Genuisin (2013) tutkimuksen tapaan myös tämän tutkimuksen tuloksissa kävi ilmi, että terveydenhuollon ammattilainen saattoi olla enemmänkin konsultin tai yhteistyötahon asemassa kuin pääasiallisena tiedonlähteenä. Tällöin harvinaissairaan henkilökohtainen auktoriteetti korostui. Myöskään lääketieteellisen kognitiivisen auktoriteetin korostuminen ei poissulkenut henkilökohtai- 
sen auktoriteetin merkitystä, vaan pikemminkin ne täydensivät toisiaan. Genuisin (2013) tutkimustuloksissa tämä ilmeni potilaan ja ammattilaisen jaettuna päätöksentekona. Myös Stanarević Katavićin (2019) tutkimuksessa kävi ilmi, että lääkärit olivat sekä tiedonlähteitä että yhteistyötahoja tiedonhankinnassa. Tiedonlähteiden yhdistely auttoi rakentamaan monipuolisen kuvan omasta harvinaissairaudesta. Tätä tiedon yhdistelyä voidaan pitää uuden tiedon luomisena, mikä saattoi olla oma-aloitteista ja aktiivista. Uuden tiedon luomisessa tärkeitä eivät olleet vain toisen käden lähteet, vaan myös oman kokemuksen kautta muodostunut ensimmäisen käden tieto. Tulosten pohjalta voidaankin päätellä, että vankka tietopohja omasta harvinaissairaudesta helpotti myös tiedon sekä tiedonlähteiden luotettavuuden arviointia.

Myös vertaiset koettiin tärkeiksi tiedonlähteiksi ja he saivat kognitiivisen auktoriteetin aseman varsinkin arkielämää helpottavan käytännönläheisen ja kokemustiedon kohdalla. Vertaistiedolla oli merkittävä rooli tämän tutkimuksen yhteydessä, kun taas henkinen vertaistuki ei korostunut tuloksissa. Usein henkistä vertaistukea oli saatu jo varhaisemmassa sairauden vaiheessa ja lisäksi tutkimuksessa korostuivat kognitiiviset, tiedolliset tarpeet. Vertaistiedon ja -tuen merkitys on noussut esiin useissa aiemmissa tutkimuksissa tai selvityksissä (Lasker ym. 2005, Gundersen 2011, Laitinen ym. 2013, Kalmari \& Taanila 2014, Stanarević Katavić 2019). Vertaistiedon kohdalla luotettavuuden arvioinnissa vedottiin arkijärkeen sekä vertaisen omaan kokemukseen ja asiantuntijuuteen kyseisestä harvinaisesta sairaudesta. Sairauksien marginaalisuuden vuoksi vertaisten rooli tiedonlähteinä saattaa korostua harvinaisten sairauksien kontekstissa enemmän kuin yleisemmissä sairauksissa.

Sairauskäsitys ilmeni harvinaissairaiden käyttämissä tiedonlähteissä erityisesti sairauden hallinnan ja aikajanan sekä sairausidentiteetin osalta. Sairautta ja sen aiheuttamia oireita pyrittiin hallitsemaan asiantuntijoilta, vertaisilta ja omien kokemusten kautta saadulla tiedolla. Lisäksi esille tuli yhteistyö terveydenhuollon ammattilaisen kanssa, kun sairauden hallinnalle pohdittiin keinoja yhdessä. Tietojen yhdistely eri lähteistä auttoikin rakentamaan harvinaisesta sairaudesta monipuolisen kuvan, mikä vaikutti sairausidentiteetin muotoutumiseen sairauden eri aikoina. Tämä ilmeni myös Litzkendorfin ja muiden (2020) tutkimustuloksissa siten, että järjestöiltä ja lääkäreiltä saatu tieto auttoi paikkaamaan kysymyksiä, joihin harvinaissairaat tai heidän sukulaisensa eivät saaneet tarpeeksi tarkkoja vastauksia internetin tiedonlähteistä sairauden alkuvaiheessa. Lääkärit olivat hyviä tiedonlähteitä lääketieteellisiin tiedontarpeisiin, kun taas potilasjärjestöt tarjosivat paljon tietoa arkielämän tueksi sekä sairauden ymmärtämisen syventämiseksi (Litzkendorf ym. 2020). Stanarević Katavićin ja muiden (2016) tutkimuksessa taas ilmeni, että vertaisten käyttäminen tiedonlähteenä ei ollut merkittävästi yhteydessä 
sairauskäsitykseen, mutta sen sijaan samaa sairautta sairastavan vertaisen tunteminen lisäsi niin hallinnan tunnetta kuin ymmärrystäkin omasta sairaudesta. Myös tämän tutkimuksen tuloksissa ilmeni, että samaa sairautta sairastavan vertaisen tapaaminen antoi mahdollisuuden oman sairausidentiteetin kehittymiselle.

Erityisesti uusi tieto omasta sairaudesta saattoi muokata sairausidentiteettiä merkittävästi. Tiedon saannin oikea-aikaisuus ja tiedon mahdolliset vaikutukset sairausidentiteetin muotoutumiseen nousivat myös esille. Tätä tukee osittain Stanarević Katavićin ja muiden (2016) tutkimustulos: heidän tutkimuksessaan vastaajat, jotka kokivat löytävänsä tietoa hyvin omalla äidinkielellään, kokivat myös sairauden ymmärtämisen sekä hallinnan positiivisemmin. Toisaalta heidän tutkimuksessaan aktiivisuus tiedonhankinnassa yhdistyi huoleen omasta sairaudesta, mutta ei sairauden parempaan ymmärtämiseen tai hallintaan (Stanarević Katavić ym. 2016).

Tärkeiksi koetut tiedonlähteet muuttuivat sairauden eri aikoina oman asiantuntijuuden kasvaessa. Tutkimus tukee ajatusta siitä, että terveystiedon hankinta voidaan ymmärtää keinoksi sopeutua sairauteen (Spring 2014a) ja tiedonhankinta voi vaihdella sairauden aikajanalla (Stanarević Katavić 2019). Tämän tutkimuksen tuloksissa sairauden aikajana ilmeni myös siten, että luotetut ja vakiintuneet tiedonlähteet, kognitiiviset auktoriteetit, olivat muodostuneet vähitellen, ja tämä vakiintuminen helpotti tiedon sekä tiedonlähteiden luotettavuuden arviointia. Nämä tulokset vahvistavat käsitystä auktoriteettikäsitysten kehittymisestä (Wilson 1983) sairauden aikana. Myös Litzkendorfille ja muille (2020) selvisi, että tiedon laadun arviointi helpottui sairauden tullessa tutummaksi. Tästä tutkijat päättelivät, että eri tiedonlähteiden tärkeys vaihtelee esimerkiksi tietämyksen tason sekä sairausvaiheen mukaan (Litzkendorf ym. 2020).

Tutkimuksen tulokset tarjoavat uutta tietoa harvinaissairaiden kognitiivisista auktoriteeteista sekä tiedonlähteiden luotettavuuden arvioinnin tavoista. Tuloksia ei voida yleistää kaikkiin harvinaissairaisiin aikuisiin suomalaisiin. Ne kuitenkin lisäävät ymmärrystä erilaisten tiedonlähteiden roolista ja merkityksestä tilanteessa, jossa tiedon puute on keskeinen sairautta määrittelevä tekijä. Tulokset tarjoavat tietoa myös sairauskäsityksen ulottuvuuksien ilmenemisestä tavoissa hyödyntää erilaisia tiedonlähteitä ja arvioida niiden luotettavuutta. Tutkimuksen tulokset vastasivat aiempien tutkimusten tuloksia erityisesti harvinaissairaiden käyttämien tiedonlähteiden osalta: tärkeiksi nousivat erityisesti digitaaliset tiedonlähteet (Carpenter ym. 2011, Gundersen 2011, Laitinen ym. 2013, Tozzi ym. 2013).

Kerätty tutkimusaineisto on käyty läpi useasti ja sitä on pyritty tarkastelemaan monesta eri näkökulmasta. Aineisto oli sisällöllisesti rikasta ja sitä oli 
runsaasti haastateltujen pienestä määrästä huolimatta. Haastattelujen määrää voitiin pitää riittävänä, sillä niiden jälkeen oli mahdollista havaita aineiston kyllääntymistä (Tuomi \& Sarajärvi 2002, Hirsjärvi ym. 2009). Tutkimustuloksia tarkasteltaessa on otettava huomioon, että suurin osa haastatelluista oli jollakin tavalla koulutuksellisesti tai ammatillisesti tekemisissä terveydenhuollon tai sairaanhoidon kanssa. Aineiston analysoijan omat harvinaissairauskokemukset on pyritty ottamaan tietoisesti huomioon aineistoa analysoitaessa. Kokemukset ovat toisaalta mahdollistaneet myös haastateltujen parempaa ymmärtämistä. Myös laajalla taustoituksella on pyritty lisäämään tutkimustulosten luotettavuutta.

Koska harvinaisia sairauksia on toistaiseksi tutkittu vain vähän informaatiotutkimuksen alalla, aihepiirin tutkiminen on tarpeellista. Tutkimuksissa on syytä ottaa huomioon harvinaissairauden kesto sekä sairauden alkamisen ajankohta, sillä nämä voivat vaikuttaa informaatiokäyttäytymiseen. Hedelmällinen jatkotutkimuksen aihe olisi uuden tiedon luominen, sillä tutkimuksen tuloksissa erityisesti tiedon jakamisen yhteydessä nousi esille uuden tiedon luominen vuorovaikutteisesti terveydenhuollon asiantuntijoiden kanssa. Myös harvinaissairaiden informaatiolukutaidon tutkiminen olisi hyödyllistä, sillä tämän tutkimuksen tulokset viittasivat kehittyneeseen valmiuteen tieteellisen tiedon arviointiin. Ilmiö vaatii kuitenkin lisätutkimusta tämän tutkimuksen haastateltujen koulutuksellisen ja ammatillisen erityisyyden vuoksi.

Tutkimuksessa nousi esille kiinnostavia terveydenhuollon käytäntöjä koskevia tuloksia. Terveydenhuollon ammattilaisten empaattisuus harvinaissairasta ja tämän tilannetta kohtaan oli tutkimuksen mukaan tärkeää luottamuksen syntymiselle. Terveydenhuollon ammattilaisilta toivottiin myös rohkeutta pyytää toisten asiantuntijoiden konsultaatiota silloin, kun heidän oma tietämyksensä ei ollut riittävää. Tutkimuksen tulokset antavat viitteitä siitä, että harvinaissairaan omaa asiantuntemusta kyseisestä harvinaisesta sairaudesta tulisi arvostaa ja hyödyntää terveydenhuollossa enemmän.

\section{Kiitokset}

Tutkimusta on rahoittanut Suomen Akatemia (n:o 321266). Kiitos kaikille tutkimukseen osallistuneille. 


\section{Lähteet}

Brüssow, H. (2013). What is health? Microbial Biotechnology, 6(4), 341-348. https://doi. org/10.1111/1751-7915.12063

Carpenter, D. M., Devellis, R. F., Hogan, S. L., Fisher, E. B., Devellis, B. M., \& Jordan, J. M. (2011). Use and perceived credibility of medication information sources for patients with a rare illness: Differences by gender. Journal of Health Communication, 16(6), 629-642. https:// doi.org/10.1080/10810730.2011.551995

Euroopan komissio (2020). Rare diseases. Viitattu 12.10.2020. https://ec.europa.eu/health/ non_communicable_diseases/rare_diseases_fi

Eurordis (2020). What is rare disease? Viitattu 21.11.2020. https://www.eurordis.org/content/ what-rare-disease

Genuis, S. K. (2013). Social positioning theory as a lens for exploring health information seeking and decision making. Qualitative Health Research, 23(4), 555-567. https://doi. org/10.1177/1049732312470029

Grut, L., \& Kvam, M. H. (2013). Facing ignorance: People with rare disorders and their experiences with public health and welfare services. Scandinavian Journal of Disability Research, 15(1), 20-32. http://doi.org/10.1080/15017419.2011.645870

Gundersen, T. (2011). 'One wants to know what a chromosome is': The internet as a coping resource when adjusting to life parenting a child with a rare genetic disorder. Sociology of Health and Illness, 33(1), 81-95. https://doi.org/10.1111/j.1467-9566.2010.01277.x

Hamilton, J. G., Hutson, S. P., Frohnmayer, A. E., Han, P. K. J., Peters, J. A., Carr, A. G., \& Alter, B. P. (2015). Genetic information-seeking behaviors and knowledge among family members and patients with inherited bone marrow failure syndromes. Journal of Genetic Counseling, 24(5), 760-770. https://doi.org/10.1007/s10897-014-9807-3

Harvinaiset-verkosto (2020a). Harvinaissairaudet. Viitattu 21.11.2020. https://harvinaiset.fi/ diagnoosit/harvinaissairaudet/

Harvinaiset-verkosto (2020b). Monimuotoinen vertaistuki. Viitattu 29.6.2020. https:// harvinaiset.fi/vertaistukea/monimuotoinen-vertaistuki/

Hirsjärvi, S., \& Hurme, H. (2008). Tutkimushaastattelu: Teemahaastattelun teoria ja käytäntö. Gaudeamus.

Hirsjärvi, S., Remes, P., \& Sajavaara, P. (2009). Tutki ja kirjoita (15. uud. p.). Tammi.

Huttunen, J. (2020). Mitä terveys on? www.terveyskirjasto.fi. Lääkärikirja Duodecim. Kustannus Oy Duodecim. https://www.terveyskirjasto.fi/terveyskirjasto/tk.koti?p_artikkeli= dlk00903 (käytetty 31.7.2021).

Huyard, C. (2009). What, if anything, is specific about having a rare disorder? Patients' judgements on being ill and being rare. Health Expectations, 12(4), 361-370. https://doi.org/10.1111/ j.1369-7625.2009.00552.x

Kalmari, S., \& Taanila, P. (2014). Vertaistuki Facebook-ryhmissä: Pitkäaikaissairaiden ja vammaisten lasten/nuorten vanhempien ajatuksia vertaistuesta Facebook-ryhmissä. Noriokeskus.

Kuula, A. (2011). Tutkimusetiikka: Aineistojen hankinta, käyttö ja säilytys (2. uud. p.). Vastapaino. 
Kylmä, J., \& Juvakka, T. (2007). Laadullinen terveystutkimus. Edita.

Laitinen, M., Malkamäki, A., Saari, K., \& Vataja, P. (toim.) (2013). Olen harvinainen: Harvinaisiin sairaus-ja vammaryhmïn kuuluvien kokemuksia ja ajatuksia palveluista, vertaistuesta ja arjen haasteista. [Suomen Reumaliitto], Harvinaiset-verkosto.

Lasker, J. N., Sogolow, E. D., \& Sharim, R. R. (2005). The role of an online community for people with a rare disease: Content analysis of messages posted on a primary biliary cirrhosis mailinglist. Journal of Medical Internet Research, 7(1), e10. https://doi. org/10.2196/jmir.7.1.e10

Leventhal, H., Bodnar-Deren, S., Breland, J. Y., Hash-Converse, J., Phillips, L. A., Leventhal, E. A., \& Cameron, L. D. (2012). Modeling health and illness behavior: The approach of the commonsense model. Teoksessa A. Baum, T. A. Revenson \& J. E. Slinger (toim.), Handbook of health psychology (2nd ed.) (pp. 3-35). Psychology Press.

Litzkendorf, S., Frank, M., Babac, A., Rosenfeldt, D., Schauer, F., Hartz, T., \& von der Schulenburg, J.-M. G. (2020). Use and importance of different information sources among patients with rare diseases and their relatives over time: A qualitative study. BMC Public Health, $20,860$. https://doi.org/10.1186/s12889-020-08926-9

McKenzie, P. J. (2003). Justifying cognitive authority decisions: Discursive strategies of information seekers. The Library Quarterly, 73(3), 261-288. https: //doi.org/10.1086/603418

Mooney, J., Poland, F., Spalding, N., Scott, D. G. I., \& Watts, R. A. (2013). 'In one ear and out the other - it's a lot to take in': A qualitative study exploring the informational needs of patients with ANCA-associated vasculitis. Musculoskeletal Care, 11(1), 51-59. https://doi. org/10.1002/msc.1030

Morgan, T., Schmidt, J., Haakonsen, C., Lewis, J., Rocca, M. D., Morrison, S., . . . Kaphingst, K. A. (2014). Using the internet to seek information about genetic and rare diseases: A case study comparing data from 2006 and 2011. JMIR Research Protocols, 3(1), e10. https://doi. org/10.2196/resprot. 2916

Neal, D. M., \& McKenzie, P. J. (2011). Putting the pieces together: Endometriosis blogs, cognitive authority, and collaborative information behavior. Journal of the Medical Library Association, 99(2), 127-134. https://dx.doi.org/10.3163/1536-5050.99.2.004

Orphanet (2012). About rare diseases. Viitattu 19.2.2018. http://www.orpha.net/consor/cgi-bin/ Education_AboutRareDiseases.php?lng=EN

Rotonen, A. (2020). Aikuisten harvinaissairaiden sairaus-ja terveyskäsitykset suhteessa heidän informaatiokäyttäytymiseensä. Informaatiotutkimuksen pro gradu -tutkielma. Oulun yliopisto. http://urn.fi/URN:NBN:fi:oulu-202011033086

Savolainen, R. (2008). Everyday information practices: A social phenomenological perspective. Scarecrow Press.

Spring, H. (2014a). Health information, what happens when there isn't any? Information literacy and the challenges for rare and orphan diseases. Health Information and Libraries Journal, 31(3), 243-246. https://doi.org/10.1111/hir.12068

Spring, H. (2014b). Health 2.0 and information literacy for rare and orphan diseases. Teoksessa R. K. Bali, L. Bos, M. C. Gibbons \& S. R. Ibell (toim.), Rare diseases in the age of health 2.0 (pp. 101-113). Springer. https://doi.org/10.1007/978-3-642-38643-5_11 
Stanarević Katavić, S., Faletar Tanacković, S., \& Badurina, B. (2016). Illness perception and information behaviour of patients with rare chronic diseases. Information Research 21(1), paper 707. http://InformationR.net/ir/21-1/paper707.html

Stanarević Katavić, S. (2019). Health information behaviour of rare disease patients: seeking, finding and sharing health information. Health Information \& Libraries Journal, 36(4), 341356. https://doi.org/10.1111/hir.12261

Tozzi, A. E., Mingarelli, R., Agricola, E., Gonfiantini, M., Pandolfi, E., Carloni, E., .. . Dallapiccola, B. (2013). The internet user profile of Italian families of patients with rare diseases: A web survey. Orphanet Journal of Rare Diseases, 8, 76. https ://doi .org/10.1186/1750-1172-8-76

Tuomi, J., \& Sarajärvi, A. (2002). Laadullinen tutkimus ja sisällönanalyysi. Tammi.

Wilson, P. (1983). Second-hand knowledge: An inquiry into cognitive authority. Greenwood Press.

Zhu, X., Smith, R.A., Parrott, R.L. \& Worthington, A.K. (2018). Understanding information sharing about rare diseases: An evaluation of the NIH's website on AATD. Journal of Communication in Healthcare, 11(2), 128-139. https ://doi.org/10.1080/17538068.2018.1453434 